\title{
CONCEPTIONS FOR FINANCING A UNIVERSAL, OPEN, REPOSITORY HOSTING AND COMMUNICATION PLATFORM FOR WEB-BASED KNOWLEDGE RESOURCES
}

\author{
Maria HAJKIEWICZ-GÓRECKA \\ Faculty of Management \\ Warsaw University of Technology, Warsaw, Poland \\ e-mail: m.hajkiewicz-gorecka@wz.pw.edu.pl
}

\begin{abstract}
The subject of this paper are alternative funding schemes for a planned universal, open, repository hosting and communication platform for web-based knowledge resources for science, education and an open knowledge society. An attempt is made to estimate the amount of funding needed by analysing the costs of procuring content from foreign and domestic sources, the digitization of library resources, capital expenditures and operating expenses of the institution that will manage the SYNAT platform. Assuming that access to knowledge resources will be free of charge for specified groups or all users, the potential revenue generated by the platform is defined - mainly: directly or indirectly from the national budget and supplementally from private sources. The possible organizational and legal forms of the institution administering the SYNAT platform - public and private sector entities - are reviewed in terms of the certainty and elasticity of funding by the national budget as well as other sources, ensuring the on-going operation of the scientific and technical information system.
\end{abstract}

Key words: SYNAT platform, costs, revenue, public (national budget) and private sources of funding, organizational-legal form of the institution administering the platform.

\section{$1 \quad$ Introduction $^{1}$}

The SYNAT project will result in the creation of a universal, open, repository hosting and communication platform for web-based knowledge resources for science, education and an open knowledge society the technical and organizational basis for the National Information System for Science and Technology (Polish acronym: KSINT). The SYNAT platform is intended to contribute to the growth of Poland's intellectual capital, thereby helping to increase our economy's competitiveness. This platform is expected to perform a range of functions, primarily:

- integrating existing knowledge resources by making them accessible from a single place according to the same standards (on the Infoma scientific communication portal),

\footnotetext{
${ }^{1}$ This paper was prepared in the course of implementing Stage B8: "Long-term financing model ensuring the durability of the scientific and technical information system", realized under the direction of prof. dr. hab. J. Kisielnicki at Łazarski University, Warsaw Poland, under the SYNAT Research Task entitled "Establishment of a universal, open, repository hosting and communication platform for web-based knowledge resources for science, education and an open knowledge society. Strategic programme: Interdisciplinary interactive scientific and scientifictechnical knowledge system", financed by the National Research and Development Centre.
}

- managing the purchase of content licences from commercial providers,

- maintaining knowledge resources on its own servers (its own resources as well as the resources of external users interested in using hosting services),

- administering a portal that provides access to knowledge in the Open Access formula,

- technical maintenance of servers,

- offering advanced services for a fee.

In formulating the funding scheme for a universal, open, repository hosting and communication platform for web-based knowledge resources, two issues need to be resolved, namely:

1) funding of initial capital expenditures (furnishing the necessary assets - equipment, patents, licences etc.),

2) funding of operations.

The first case concerns assets that constitute someone's property, thus their owner's role is to create them and reproduce them for the sake of attaining specified goals. The solution to this problem is tied to the choice of organizational-legal form of the entity, which identifies the owner as well as the scope of this entity's rights and duties. 
The second issue is universal in character, independent of the entity's organizational-legal form, and boils down to specifying the sources of revenue necessary to cover operating expenses and, in the case of selffinancing organizations, ensuring funds needed for development. Regardless of whether the platform is a commercial or non-profit venture, the starting point must be identification of the expenses it will incur.

In this paper the business model recommended for the SYNAT platform is a centralized coordination system [7] - a comprehensive platform that integrates existing domestic repositories and, as needed, creates new ones, on an Open Access basis. It appears necessary, however, to establish and maintain a central repository that gathers the results of publicly funded research in Poland, which is a missing link in open access to domestic knowledge resources.

\section{SYNAT platform operating expenses}

The expenses of the SYNAT platform will include:

- costs of buying content licences from domestic and foreign publishers,

- costs of digitizing existing resources,

- current operating expenses of the institution administering the platform,

- costs of maintaining institutional and thematic repositories that function separately (do not use the hosting services of the institution administering the platform),

- costs of meta-data preparation.

\section{Content procurement costs}

In the matter of content procurement costs we should refer to the practices of Polish repositories in obtaining foreign sources of knowledge. The Ministry of Science and Higher Education (MNiSW) awarded grants of 156.7 million zł, 148.9 million zł and 144 million zł, respectively, during the years 2010-2012 [18] to cover the costs of maintaining and expanding the Virtual Library of Science - i.e. the purchase of domestic academic licences granting access to renowned foreign periodicals (a portion of these acquisitions did not include archiving rights). MNiSW subsidizes up to $50 \%$ of consortium licensing costs. It's difficult to estimate the costs that would be incurred in buying the deep resources of publishers, as they will depend on how great the demand is for access to electronic sources of knowledge made available on a commercial basis as well as the transaction prices, which are often considerably lower than listed prices because various discounts apply to them ${ }^{2}$. Access costs to domestic knowledge resources remains an open question. Also unknown are the expenditures to be incurred for nonexclusive licences, which enable all users of the platform to access scientific content.

Likewise it's difficult to estimate the costs of digitizing Polish library resources. According to the Government's "Kultura+" programme [2] adopted in 2010, the costs of implementing the "Digitization priority" over the period 2011-15 are estimated to come to 141.25 million zł, of which 120 million zł is to be covered by the national budget. The purpose of this priority is to support the digitization of cultural resources by means of buying digitization equipment, conducting the digitization process and electronically disseminating the digitized collections, including library materials, museum exhibits, relics, archives and audiovisual materials. But will these expenditures suffice to digitize all resources? The programme covers cultural resources, but scientific and technical resources, for instance, will still be left to digitize. The costs of meta-data preparation are also unknown.

In respect to content from domestic resources, we recommend open mandates, understood as the obligation to publish the results of publicly financed research in Open Access periodicals or deposit them in open repositories. "The Open Access mandate is an act issued by an authorized body of the given institution by virtue of which persons remaining in a specified relationship with this institution shall be obliged to ensure open access to the scientific content which they authored."

Making auto-archiving compulsory is the most effective method for systematically procuring repository resources. Studies have shown that if auto-archiving is a requirement, $80 \%$ of researchers will submit their works to archives [16]. The idea of forcing publication in an open repository is not new, as many institutions funding research follow this practice.

The European Commission, under the VII Framework Programme of Science, has undertaken a pilot study

\footnotetext{
${ }^{2}$ An extensive review of the world electronic resources market is contained in a report conducted under the SYNAT research task [9].

${ }^{3}$ I cite p. 143 for [6].
} 
on scientific publications that was prepared under the Programme. The Commission recommended that all research work from the Programme be made accessible in the Internet within 6-12 months [4]. Pursuant to the rules governing grants under 7FP, researchers who use EU funds in the fields of health care, power engineering, environmental protection, information technology and communications, research infrastructure, social sciences, humanities and public surveys are obliged to submit - at the same time they submit for publication - the full contents of their peerreviewed publications to a special, freely and generally accessible virtual library (the repository of their institution - if one is available - or the OpenAIRE Orphan Repository), where they will be made accessible immediately or with a certain time lag, without temporal or geographic limitations. This applies to about $20 \%$ of all projects financed by 7FP. Researchers in other fields of science may also decide to make their work accessible according to the same rules.

In the latter part of 2011, the Ministry of Science of Great Britain signalled its intention to force the publication of the results of publicly funded research in the Open Access model. The move to this model will take place provided that peer review is maintained and publication in Open Access is compulsory. One of the options guaranteeing the cost effectiveness of this process is to move from a model whereby periodicals are paid for by university libraries to a model under which researchers themselves pay for publishing. In this case, however, the researchers would receive grants to enable them to do so [5].

The rule in the USA is that scientific works based on research financed by the National Institutes of Health must be deposited in the PubMed Central data base immediately after they are accepted for publication, and made accessible no later than 12 months after publication. There, too, a discussion is under way on a regulation proposed by the government that would reduce the interval from publication to Open Access to 6 months $^{4}$ (it would apply to all scientific institutions that receive annual outlays in excess of 100 million USD). Ukraine enacted a law in 2007 that requires Open Access publication of all publicly financed research results; Lithuania has enacted a similar law. ${ }^{5}$

\footnotetext{
${ }^{4}$ More examples in [10].

${ }^{5}$ An extensive review of world practices in this area is presented in the ICM report [6], pp. 143-150.
}

Open mandates should be adopted by the institutions that finance research in Poland: National Science Centre (NCN), National Research and Development Centre (NCBiR), institutions of higher learning, Polish Academy of Sciences (PAN), scientific institutes whose employees conduct publicly financed research within their statute activity and other institutions that dispose of public funds for research grants. Private sponsors of research can be encouraged to adopt Open Access mandates by awarding them tax preferences or priority status when they apply for public funding.

This method of providing the SYNAT platform scientific and technical materials in digital format fits the support-worthy new scientific communication system, a scheme formulated by the Interdisciplinary Mathematical and Computer Modelling Centre at the University of Warsaw (ICM UW). All results of scientific and research work funded by institutions that have adopted the Open Access mandate are to be deposited in open repositories - immediately in the case of the socalled Gold Path (scientific publications in peerreviewed open access periodicals) and Green Path (researchers' auto-archiving of copies of their own work in open repositories), and after a specified time lag in the case of publications in traditional periodicals.

The final results, also often intermediate results, of publicly funded research work must be peer reviewed, with these expenses being borne by the grant provider so that the costs of verifying research quality are not incurred by the platform as the distribution channel. The costs of reviewing other archived publications should be paid by their authors, as is the case with traditional scientific periodicals. Authors should also incur the costs of preparing materials for placement in the repository, in the appropriate, standardized format.

\section{Projected operating expenses of the SYNAT platform}

The SYNAT platform operating expenses will include:

- current operating expenses of the institution administering the platform, 
Table 1. The breakdown of annual operating expenses (source: own study)

\begin{tabular}{|c|c|c|c|}
\hline \multicolumn{3}{|c|}{ type of costs } & annual \\
\hline \multicolumn{3}{|c|}{ salaries (including taxes) and additional annual remuneration including: } & $1,105,000$ \\
\hline - programmers & 2 full-time positions & $10,000 \mathrm{zl} / \mathrm{month}$ & 260,000 \\
\hline - network administrators & 2 full-time positions & $7,000 \mathrm{zl} /$ month & 182,000 \\
\hline - buyers (licence purchase) & 2 full-time positions & $7,000 \mathrm{zl} /$ month & 182,000 \\
\hline - manager & 1 full-time position & $12,000 \mathrm{zl} / \mathrm{month}$ & 156,000 \\
\hline - accounting personnel & 2 full-time positions & $5,000 \mathrm{zl} /$ month & 130,000 \\
\hline - other employees & 3 full-time positions & $5,000 \mathrm{zl} / \mathrm{month}$ & 195,000 \\
\hline rent & \multicolumn{2}{|c|}{$700 \mathrm{~m}^{2} / 15$ euro $\mathrm{m}^{2} /$ month } & $520,000 *$ \\
\hline equipment maintenance and repair & \multicolumn{2}{|c|}{$5-10 \%$ of the equipment's value } & $100,000 * *$ \\
\hline & & & $1,200,000$ \\
\hline \multicolumn{3}{|c|}{ other costs (travel, office materials, services etc.) } & $?$ \\
\hline & & total costs: & $2,925,000$ \\
\hline
\end{tabular}

* rental rates in Warsaw outside the city center, assuming an exchange rate of about $4.1 \mathrm{z} z / 1$ euro

$* * 10 \%$ of the value of the equipment in the amount of 1 million $\mathrm{z}$ is assumed

- costs of maintaining institutional and sector repositories that function separately (do not use the hosting services of the institution administering the platform).

The operating expenses of the institution administering the platform include salaries, rent, utilities, equipment maintenance and repair, travel and other office expenses. These costs were estimated on the basis of information obtained from the managers of ICM UW the leading institution coordinating the purchase of licences by consortia of institutions of higher learning and other scientific institutions. ICM UW is also responsible for acquiring and network sharing of scientific data bases under the Virtual Library of Science assuming that the platform operator functions as an autonomous entity.

The breakdown of annual operating expenses is given in Table 1. The breakdown includes "additional annual remuneration", which is a mandatory salary component in public sector entities (institutions of higher learning, executive agencies and state legal persons) - it is not mandatory for private entities.

As stated previously, we assume that the SYNAT platform operator will integrate the activities of domestic institutional and thematic repositories as well as coordinate the purchase of licences granting access to foreign sources of knowledge due to the greater bargaining power this provides, thus greater capacity to negotiate prices. It follows that the institution admin- istering the platform should employ professional buyers.

The operating budget presented above is conservative in character - it assumes, among other things, that:

- 2 programmers will be hired; the actual need in this area could fall anywhere from 1 part-time programmer to 2 full-time programmers,

- equipment maintenance and repair costs will reach the upper limit of the anticipated cost bracket - i.e. $10 \%$ of the value of the IT equipment,

- the costs of renting premises are typical Warsaw rental rates, though these figures are relatively high for rents outside the core city centre.

However, this breakdown does not include amortization of capital assets - the basic rate of depreciation for computer equipment is $30 \%$, and it can be raised by a factor of up to 2.0 , because computers as capital assets are subject to rapid technological obsolescence.

Also absent from the breakdown are "other costs", including business travel, office materials, services etc.

Electricity constitutes a significant component of operating expenses. ICM UW estimates that the current amount of electricity consumed by the Virtual Library of Science server accounts for about half of this institution's energy costs. Electricity consumption depends on server power - the greater a server's power, the greater the demand for electricity. Thus it will be important to determine the power of the computer hardware the SYNAT platform requires as a factor 
generating electricity consumption costs. It would be useful to specify the relationship increase in server power/ increase in electricity consumption.

Increased platform operating expenses could also result from the provision of added services, such as hosting keeping other entities' institutional or thematic repositories on the platform's servers, performing data search and aggregation in various profiles on demand, consulting in the area of intellectual property rights etc. These costs will depend on the scope of services offered, which on principle should be covered by the service user.

At the current stage it's difficult to calculate the costs of maintaining separately functioning (not using the hosting services of the institution administering the platform) institutional and thematic repositories, because we do not know how many such repositories will be maintained separately and how many will take advantage of the platform's hosting services.

According to ICM UW estimates, "the costs of an institutional repository would stem mainly from adaptation of the existing infrastructure and ongoing operation of the repository.

The costs for one mid-sized repository are roughly as follows:

- server installation and configuration - one-time expense: 1-3 network administrator person-months,

- system administration - fixed cost: 0.25-0.50 network administrator person-months,

- repository management (library work) - fixed cost: 2 repository manager person-months.

It's also necessary to include additional costs stemming from the establishment of an institutional support network for researchers negotiating with publishers. The most effective solution would be to locate (the elements of such a network) by the repositories. They can be expected to be needed especially during the transition period." [6, p. 228]

This estimate constitutes an appropriate starting point for calculating the costs of maintaining separately functioning (not using hosting - so-called in-house repositories) institutional repositories, although calculating the operating expenses that will be generated by all the repositories functioning in the system will require a knowledge of how many repositories there will be.

It's also difficult to estimate the costs of meta-data preparation.

\section{Capital expenditures}

Assuming that the SYNAT platform operator is an autonomously functioning entity (i.e. is not part of another institution, such as ICM, which is unit of the University of Warsaw), it will be necessary to specify the expenditures on initial capital outlays.

ICM UW estimates that about 1 million zf will be needed to cover these expenditures. Two equipment configuration variants are possible: a single, highpower server or a set of several lower-power servers whose computing power adds up to that of the single server in the first variant. The choice of variant is important in respect to future hardware replacement, which should take place every 3-5 years, depending on the pace of technological progress. In the first case the entire equipment will have to be replaced after several years; in the second case, replacement can take place gradually.

The estimated capital expenditures presented here do not take into account the hardware power $\div$ production relationship. Further factors that should be investigated are:

- whether, and to what extent, the installation of computer hardware worth 1 million zł will allow for increased content delivery and service to an increasing number of users (website traffic)?

- at what scale of "production" would it be necessary to increase "production capacity"?

Answers to these questions would enable us to specify the schedule and scale of future additional capital expenditures and the possibility of coordinating them with equipment replacement stemming from technological reasons. It should be kept in mind here that the servers' power will determine electricity costs.

A precise projection of capital expenditures will be possible only after the SYNAT platform operator variant is chosen: on the basis of ICM UW, in which case costs will be limited to the additional hardware needed; or as a whole new organization, in which case it will be necessary to build the IT infrastructure from scratch. For the purpose of covering these expenditures, the institution administering the platform can apply to the Fund for Polish Science and Technology, which is at the disposition of the minister responsible for science.

This is a special fund that is used to implement the "Programme to support research infrastructure" 
[19] - funding or co-funding can be obtained for capital expenditures on the purchase or production of scientific research apparatus needed for research. The Fund for Polish Science and Technology may also finance expenditures for purposes relating to the development of Polish science and technology, including the support of particularly important areas of research and developmental work as well as the promotion and dissemination of science. This last purpose indicates the SYNAT platform as a potential beneficiary.

\section{Revenue sources for the SYNAT platform operator}

In attempting to answer the question as to how SYNAT platform operations should be funded, it must be made clear from the start that scientific and technological information should be regarded as special public goods, also called "social goods" - that is, goods which, owing to their natural characteristics, could be provided for a fee to particular people, but which, in keeping with social and economic policy, should be provided free of charge or at subsidized rates to specified groups or to all citizens. A prerequisite for the creation of social goods is making their consumption possible by people who, due to their individual incomes, would be excluded from access to them if these goods were available only on commercial terms (for a charge) ${ }^{6}$. While social goods are financed by public funds, this does not exclude their financing by private funds. Social goods in Poland include education, health care, culture, sport, urban transportation etc. This category of goods should also include scientific and technical information, understood as universal and free access to knowledge due to its enormous importance for social and economic development. This conception of scientific and technical information implies the necessity of engaging public funds in KSINT, though it also allows for the possibility of funding from private sources. The predominant practice abroad is to fund KSINT operations from public sources.

Likewise in Poland the main source of funding for the INT system must be the government, with private funds playing a supplementary role.

\footnotetext{
${ }^{6}$ For a broader discussion of social goods in [12], see p. 32 and later.
}

\subsection{Revenue from public sources}

In connection with this, the question arises as to how to ensure continuity of funding from the national budget in a situation when:

- firstly, the national budget is established on an annual basis, yet the project is long term, and there is no guarantee that sufficient funding will be allocated to KSINT in each successive budget,

- secondly, there is a permanent deficiency of funds for public tasks, competition for the limited funds is intensifying, and science expenditures usually lose this competition.

Taking the above into account, it's necessary to specify steady, autonomous public funding sources that ensure regular revenue to cover the SYNAT platform's operating expenses. Three variants should be considered: 1) Long-term programme; 2) Income tax surcharge assessed on legal persons - an idea advanced by one of the experts supporting implementation of the SYNAT project, prof. B. Samojlika ; 3) Charging authors or the institutions with which they are affiliated for depositing research content in repositories.

1) Long-term programme (pursuant to art. 136 of the Public Finances Act [14]):

- the Budget Act may specify, within the expenditure limits for the fiscal year, limits on expenditures on long-term programmes,

- long-term programmes are established by the Government for the purpose of realizing strategies adopted by the Government, including in the areas of defence and state security. The Government, when establishing a programme, shall indicate the entity implementing it,

- the realization of long-term programmes may be divided into stages,

- entities realizing long-term programmes may incur obligations (debts), in particular years, for the purpose of financing the programme's implementation up to the total amount of expenditures specified for the entire programme. In the case of joint realization of a long-term programme by two or more entities, the obligations incurred by each entity may not exceed the amount planned for that entity.

Currently, numerous long-term programmes are under way, e.g. the previously mentioned Kultura + pro-

\footnotetext{
${ }^{7}$ Opinions of experts in [8].
} 
gramme. The establishment of such a programme ensures funding or co-funding throughout the period it's in effect and allows for phased implementation of complex, long-term projects. The degree to which the final goal has been achieved is specified at each stage.

When recommending a long-term programme as a way to ensure funding to launch and develop the SYNAT platform, it's necessary to set a final goal and sub-goals to be met at each stage - e.g. the degree to which repositories are open, or the ratio of publications in open access to publications resulting from publicly funded grants, or both these metrics and the degree to which they are realized each year. It's also necessary to specify the expenditures toward realization of the final goal - for this reason cost calculations are important, as well as co-financing, when possible, by the beneficiaries of public funds.

The minister for digitization should be in charge of the long-term programme. The SYNAT platform could be the operator of such a long-term programme, and the final beneficiaries would be the repositories - participants in KSINT.

2) An income tax surcharge on legal persons, proposed by prof. B. Samojlik, former Minister of Finance. Assuming a Corporate Income Tax (CIT) surcharge of e.g. $5 \%$ at the current $19 \%$ CIT rate and revenue from this tax exceeding 38 billion $\mathrm{zt}$ in 2011 - the surcharge rate would be $19 \% * 0.05=0.95 \%$, which would yield over 360 million $\mathrm{zl}$ in extra revenue to be allotted to the SYNAT project.

This revenue would suffice not only to cover the platform's operating expenses, but also to finance the purchase of licences for access to foreign sources and digitization of scientific library resources. Revenue from CIT can vary according to the state of the economy in the given year, but this revenue would be earmarked for the SYNAT project. Such a solution, though it would require amendments to the CIT Act, would provide an opportunity to market the "innovative" financing of research by business in exchange for free access to the results of this research. It should be noted that CIT surcharges, and surcharges on various taxes, are widespread in the EU. It's also worth considering the option of using income from the CIT surcharge to fund the long-term programme discussed in the previous point.

3) Fees for depositing scientific content in repositories - this would amount to indirect public funding due to the fact that over $90 \%$ of scientific research in Poland is financed from the national budget, and researchers would include this fee in the costs covered by their grants. In this variant, the main source of funding should be revenue from fees for mandatory autoarchiving the results of publicly funded research in repositories integrated with the SYNAT platform. Special grants for conducting projects to the NCN and NCBiR in 2012 amounted to nearly 2 billion zł, which should be added to the 2 billion $\mathrm{zl}$ allocated to scientific institutions to perform their statutory activity. If the operating expenses of the entities integrated with the SYNAT platform amounted to 10 million zł (the amount estimated by experts), then a $0.25 \%$ allocation from all government expenditures on scientific research would suffice to cover these costs. If this funding variant for the platform were adopted, then in addition to introducing the obligation of disseminating the results of publicly funded research, it will be necessary to impose a fee for depositing these works in Open Access archives in order to ensure revenue for the repositories collecting these resources. The repositories would thus gain a steady source of income - their main source of revenue would be fees for auto-archiving publicly funded research works, to be paid by their authors or the institutions with which they are affiliated. The obligation to disseminate scientific research results in Open Access should be a research grant selection criterion, and the costs of meeting this obligation should be included in the research project cost estimate.

The imposition of fees on the authors of publicly funded Open Access publications means that these costs will still be incurred by the national budget, as they will show up in the cost estimates of research grants. But a change in the funding scheme will occur - in the traditional model, it was the libraries of scientific institutions which, for and on behalf of readers, incurred the costs of providing publications. The employees of these institutions decided the contents of their libraries, which did not always satisfy or suffice for all users. But an Open Access virtual library is filled by research authors, and its contents may be incomparably larger and adapted to the needs of all users. This represents added value in the SYNAT business model.

The question arises as to how much to charge for autoarchiving. The costs of publishing a typical article in a professional printed journal are estimated to amount to $1-3 \%$ of the costs of the research necessary to create it. Publishing costs mainly consist of expendi- 
tures on evaluating the scientific value of an article and editing it, which are easy to calculate. But the cost of depositing and storing one article on a server cannot be calculated directly - thus, certain estimates have to be made, such as the relation of repository network operating expenses to:

- expenditures on science, as indicated above,

- the number of publications auto-archived per year,

- the total size of auto-archived files or some other metric.

\subsection{Supplementary revenues - private sources}

The SYNAT platform could derive revenues from added services, including:

- hosting resources provided on the platform's servers for other institutions' repositories,

- on-demand searches according to various criteria,

- consulting in the area of intellectual property rights,

- advertising - e.g. for periodicals which, during the [pre-publication] waiting period, provide articles on-line for a fee, or for institutions of higher education,

- providing access to users outside the regular authorized group,

- sponsoring by private individuals and institutions.

If access to the platform's resources were gradually opened to successive user segments, fees could be charged during the transition period to persons otherwise unauthorized to access the content. Finally, when the platform reaches maturity and full openness, sales of services by knowledge and innovation brokers should be included in its offering, to which the authors of a Jagellonian University report call attention [13].

Regardless of the platform's main sources of revenue, it should seek business partners who would be interested in supporting selected aspects of the platform's activities. These could be industrial corporations that support the delivery of appropriately processed knowledge to particular user segments, publishers interested in attracting attention amongst a broad range of potential readers, IT sector manufacturers interested in their products being used by a renowned organization, Internet search engines, repositories outside the INT system and others.

To recapitulate, the SYNAT platform's main revenue stream should come from public sources, and appropri- ate legal regulations would need to be adopted for each of the three public funding variants. Other, non-public funding sources - mainly from sales of services would be supplementary in character.

\section{$7 \quad$ Proposed organizational-legal solutions}

Assuming a centralized coordination system as well as public and non-public funding, the choice of organizational-legal forms for the institution administering the SYNAT platform is broad, ranging from public sector entities (executive agency, state legal person), through public law foundation, to commercial companies. The choice should be determined by the outlook for ensuring the long-term continuity of funding, thus the continuity of KSINT operations.

The main organizational form for conducting largescale business activity is the commercial company. Organizing business activity in the form of capital companies is advantageous due to the limitation of liability for the company's obligations to the company's assets; shareholder liability is limited to their contributions to the company. Capital companies have fairly formalized structures, since they regulate the rules of shareholders' limited liability. Limited Liability companies (sp. z o.o.) have less formal structures, while Joint-Stock companies (S.A.) are more formalized.

However, due to the character of the product offered by the analysed project (social goods), and the fact that public funds constitute the main revenue stream of the institution administering KSINT, the form of organization that should be considered first is public sector entity. Among the public sector entities mentioned in the Public Finances Act [8] as organizational-legal forms, the SYNAT platform operator should consider executive agency and state legal person. The main differences between these solutions boils down in practice to the character of their revenue sources - executive agencies obtain the funding they need to perform their tasks primarily in the form of national budget allocations $(56,3 \%$ of total revenue in the draft 2012 national budget act) or revenue derived from administration of state assets entrusted to them, while state legal persons have defined on going sources of revenue and do not obtain significant budget allocations $(2,6 \%$ of total revenue in the draft 2012 national budget act) [3]. 


\subsection{Executive agency}

These agencies are heterogeneous entities in organizational and legal structure, and there is no legal definition of them. Government entities called agencies may function (or functioned in the past) in the form of JointStock companies in which the State Treasury is a shareholder, State Treasury foundations, budgetary units, budgetary institutions and finally legislatively established state legal persons. This part of the paper refers to the latter type and is intended to provide an abbreviated presentation of the most important elements of government agencies functioning as legal persons.

Examples of government entities functioning as executive agencies include the National Science Centre, National Centre for Research and Development and Polish Agency for Enterprise Development. Agencies perform a variety of tasks, which can be grouped as follows:

1) managing assets belonging to the State Treasury, including buying and selling;

2) privatizing and managing state reserves (ARR, ANR, AMW, WAM);

3) implementing government policy within designated areas, by means of intervention, restructuring, promotion, information provision, education and social activities (NCBiR, NCN, ARR, ARiMR, ANR, PARP);

4) conceptual work, planning and design (ARR);

5) attracting foreign investments and supporting activities to promote Poland abroad (PAIiIZ).

The tasks of agencies and the tools for performing them are defined in the legislative acts that establish them. However, in several cases - e.g. Agency for Restructuring and Modernization of Agriculture, Polish Agency for Enterprise Development - the legislature delegated the specification of tasks, directions of activity and means of implementation to executive regulations.

Government agencies are supervised by the Prime Minister and other ministers depending on the type of agency and the ministry to which it is subordinated. The officer directing and representing the agency is its president, who is most often appointed by the Prime Minister at the request of the minister supervising the agency.

The Public Finance Act of 27 August 2009 [8] introduced a new form of public sector entity, the executive agency. This entity form is new in that the Act uni- formly specifies certain general rules governing the financial management of entities hitherto called "state agencies" or "state government agencies". The rules previously governing the financial management of these agencies were specified in the legislative acts that gave birth to them. Now, the Public Finance Act provides for the financial management of executive agencies based on the provisions of this act as well as the act that established the given agency.

An executive agency is a state legal person established pursuant to a separate act for the purpose of performing government tasks. It's a solution modelled after common practice in the EU, where the performance of particular tasks is entrusted to executive agencies, not only EU bodies. In Poland, these tasks had been performed by a certain portion of the so-called government agencies. An executive agency acquires legal personality by the legislative act that establishes it. This act should also specify whether, and in what registry, this fact is noted.

The basis for the financial management of an executive agency is its annual financial plan, consisting of the following items:

1) revenue from activities conducted;

2) allocations from the national budget;

3) cost breakdown:

a) agency operations,

b) performance of statutory tasks, with a specification of the costs of performing these tasks by other entities, including salaries and contributions [taxes] assessed on them, interest payments resulting from incurred obligations and purchases of goods and services;

4) financial result;

5) funds for capital expenditures;

6) funds granted to other entities;

7) assets and liabilities at the beginning and end of the year;

8) cash and cash equivalents at the beginning and end of the year.

The executive agency financial plan constitutes an annex to the Budget Act, while its financial statement constitutes an annex to the Report on the Implementation of the National Budget.

An executive agency financial plan has a structure typical of any public sector entity. However, it also has certain differences. The first is the obligation to draw 
up the agency's revenue and expenditure plan according to time of payout. The second is the requirement to ensure that the agency's planned revenues and expenditures are balanced, although this requirement may be waived by the agency's supervisory body in consultation with the Minister of Finance. The third difference is the imposition of limitations on changes in an agency's financial plan. The fourth is the imposition of restrictions on incurring obligations for implementation of a given task over a period exceeding the fiscal year. The fifth is that an agency may receive allocations from the national budget without precisely specifying the character of the allocations. This means that an executive agency's financial autonomy, as a separate legal person, is very limited.

An executive agency is required to pay surplus funds remaining after payment of all taxes (as determined at the end of each year), into the national budget. However, the Government, at the request of the minister supervising the given agency, may agree (in the form of a resolution) to waive this requirement. The reason for requiring executive agencies to pay their surplus funds into the national budget is the non-profit character of these agencies - since they cannot keep surplus funds (profits) for themselves, they should not be motivated to generate them.

Currently, agencies are also obliged to comply with the Public Procurement Act. The State Treasury is not liable for the obligations of agencies, and agencies are not liable for the obligations of the State Treasury, although this rule does not apply, for obvious reasons, to agencies performing tasks for or on behalf of the State Treasury (WAM, AMW, ARM) [22, p. 13].

The detailed provisions governing financial and asset management by executive agencies lie in the legislative acts establishing them, their statutes (charters) and numerous executive regulations which apply to particular agencies.

The powers and duties of an agency relating to financial management include: incurring short-term loans, incurring long-term loans, issuing bonds, obtaining guarantees from the State Treasury for obligations arising from the aforementioned actions, granting guarantees for loans, subsidizing interest payments on loans, issuing loans or grants, funding or co-funding supported enterprises, acquiring and taking over shares and stock in commercial companies, acquiring bonds issued by enterprises, selling debts.
If the SYNAT platform operator functioned in the form of an executive agency, its revenue would consist of:

- earmarked allocations to cover operating expenses,

- special allocations to buy licences for scientific data bases,

- allocations for capital costs,

- other revenue, e.g. income from the sales of services, interest earned on funds in bank accounts etc.

Supervision of the SYNAT platform in the form of an executive agency would be exercised by the Ministry of Administration and Digitization, which wants to uniformly standardize the rules governing access and use of publicly funded knowledge resources, [and] declares that its aim is the openness of public knowledge resources, understood as information resources of special importance for the innovation and development of an information society as well as other sources of knowledge and cultural content belonging to cultural, scientific and educational institutions [11]. The Ministry of Science and Higher Education, Ministry of Culture and National Heritage and Ministry of Education should also be administrators of funds granted to cover the platform's activities.

If the platform is organized as an executive agency, its continuity of funding will depend on the state of the national budget. If difficulties arise expenditures may have to be cut, and often planned capital expenditures are the first items crossed off the budget, which could pose a threat to the normal functioning of the platform.

\subsection{State legal person}

Examples of state legal persons are the Office of Technical Inspection, Polish Centre for Accreditation, Polish Air Navigation Services Agency, the Polish Film Institute and the Social Security Administration (ZUS). State legal persons ${ }^{8}$, like executive agencies, are established pursuant to separate legislative acts. They pursue the economic aims of the state and perform specified public functions.

The basis of the financial management of state legal persons is a financial plan, drawn up pursuant to the

\footnotetext{
${ }^{8}$ A state legal person should be understood as an organizational unit other than the State Treasury, having a legal personality, whose property is entirely state property. Act of 8 August 1996 on the Rules Governing the Exercise of Treasury Powers (Journal of Laws 1996, No. 106, pos. 493, as amended).
} 
legislative acts establishing them, taking into consideration provisions of the Public Finances Act, and presented to the Minister of Finance in the manner and within the time limits specified in the regulations governing preparation of the Budget Act. These entities manage their finances autonomously, covering expenditures on their legally defined tasks with their own funds and revenues they obtain. They have their own assets which constitute state property in an economic sense, but they are not liable for obligations incurred by the State Treasury. They may use the revenue they obtain to make capital expenditures. Depreciation of capital assets is included in their operating expenses.

State legal persons obtain revenue from the activity they conduct and from national budget allocations. Revenue from activity includes fees for actions/ services performed for other entities. Performance of these actions is mandatory. The relatively steady demand for these services (the performance of particular actions is often a requirement that must be satisfied before an enterprise, or its products or services, can enter the market) ensures stable revenue for entities with the status of state legal person.

If the SYNAT platform operator had the status of a state legal person, its revenue would consist of:

- income from the basic activity it conducts,

- special allocations to buy licences for scientific data bases,

- other revenue, e.g. income from the sales of added services, income from assets, interest earned on funds in bank accounts, other revenue etc.

As in the case of executive agencies, the SYNAT platform operator as a state legal person should be subject to supervision by the Ministry of Administration and Digitization, and the Ministry of Science and Higher Education, Ministry of Culture and National Heritage and Ministry of Education should also administrate funds granted to cover the platform's activities.

\subsection{Foundation}

Because the SYNAT platform operator performs tasks of a public nature, and should be funded by the national budget, it could assume the form of a public foundation, which, though not considered to be public sector entity, may receive public funding.
An example of a public foundation is the Public Opinion Research Centre (CBOS), which was established by a legislative act [1].

The Law on Foundations of 6 April $1984^{9}$ does not contain a direction definition of a foundation, mentioning only its basic characteristics:

- a foundation is established to pursue socially or economically useful aims that are consistent with the basic interests of the state, in particular: health care, economic and scientific development, education, culture and art, social security, environmental protection and conservation of historical monuments,

- founders may be any natural persons, regardless of citizenship and place of residence,

- a foundation is a legal person, and it acquires legal personality the moment it is entered in the National Court Register,

- a foundation is under the supervision of state bodies, although all decisions concerning the foundation itself - including entry in the register, repeal of resolutions adopted by the board, suspension of the board or liquidation of the foundation - are made by the registration court,

- after it is registered, a foundation functions at the request of the minister within whose purview the foundation's purpose lies or the provincial governor.

The constitutive elements of a foundation according to Polish law are: 1) assets, 2) public purpose, 3) noncorporate organizational structure that has a legal personality.

The following types of foundations can be distinguished:

- private and public foundations: Polish law allows the establishment only of foundations with a public purpose - i.e. serving the interest of some unspecified group of beneficiaries,

- private law and public law foundations: the former are established pursuant to provisions of private law, i.e. by way of legal actions; the latter type of foundation is established by legislative or administrative acts; a regulation under the Law on Foundations currently makes it impossible to establish a foundation by way of acts issued by state bodies,

\footnotetext{
${ }^{9}$ Journal of Laws 1991, No. 46, pos. 203, as amended.
} 
- non-profit and not-for-profit foundations: the former cannot conduct business activity, and their assets are funded solely by gifts, bequests, grants etc.; pure non-profit foundations are very rare in Poland; notfor-profit foundations are more frequent; this type of foundation may conduct business activity, but all revenues it obtains must be devoted to the foundation's statutory activity; profits must also be devoted to covering the foundation's operating expenses or maintaining its capital.

Foundations may be established by natural persons or legal persons. While they may not be established by the State Treasury, they can be created by provincial and district (powiat) governments.

A foundation's charter (statute) may contain a provision enabling it to conduct business activity. Such a provision, however, is optional, and its absence would merely render the foundation incapable of conducting business activity. For-profit business activity may not be the means by which a foundation realizes its main goals. Not-for-profit business activity (in which fees are collected only to cover necessary operating expenses) may be a means by which a foundation pursues its goals, thus it may be properly regarded as lying within the meaning of a foundation's statutory activity, but only when it is consistent with the public interest - that is, it's the only way to satisfy particular social needs; thus, only business activity that lies within this scope is consistent with a foundation's statutory activity. In practice this means that a foundation must address its activity to people whose needs are not satisfied according to regular market principles. Conducting profit-making business activity is essentially the only way to obtain funds for a foundation's statutory activity, thus it performs a subsidiary function in relation to pursuit of a foundation's non-profitmaking goals. This business activity must conform and be subordinated to the foundation's statutory activity that is, at least the majority of income from a foundation's business activity must be devoted to its statutory goals [21, pp. 157-158].

If the SYNAT platform operator had the status of a foundation, its revenues could consist of:

- income from statutory activity,

- special grants to buy licences for scientific data bases,

- grants, donations, legacies and bequests,
- other revenue, e.g. income from the sales of added services, income from assets, interest earned on funds in bank accounts, other revenue etc.

A foundation - in contrast to the other organizationallegal forms presented earlier (executive agency, state legal person) - may obtain revenue from grants, donations, legacies and bequests, which opens the way to financing by its founders. However, it must apply for grants on a competitive basis. Revenue from activities would provide the platform operator as a foundation steady funding for its operations, while the costs of buying licences would be covered by the national budget and donations.

\subsection{State institution in the form of a joint-stock company}

Another possible organizational model for the SYNAT platform operator is joint-stock company. We will present two solutions here: joint-stock company with the status of a public benefit company and non-profit public company modelled after the National Depository for Securities.

The joint-stock company is an organizational-legal form meant for conducting larger-scale business activity. Consequently, its regulations are the most formalized of all the regulations governing the various organizational forms of enterprises.

A joint-stock company may be formed for any legally permitted purpose, not only for conducting business activity, by one or more persons (though it cannot be founded by a single-member limited liability company). Joint-stock companies can be divided into private and public companies. The latter are characterized primarily by the fact that their shares are publicly traded ${ }^{10}$. To establish a joint-stock company it's necessary to organize it, make contributions that cover the share capital in its entirety, appoint a board of directors and supervisory board, and enter the company in the register. Only at the moment a joint-stock company is entered in the register does it acquire a legal personality.

A joint-stock company, as an entity separate from its shareholders, is solely liable for its obligations - thus, its shareholders incur no liability for its debts.

\footnotetext{
${ }^{10}$ See art. $4 \S 1$ pt. 6 of the Commercial Companies Code in connection with art. 4 pt. 20 Act of 29 July 2005 on Public Offerings, the Conditions Governing Introduction of Financial Instruments into Organised Trading, and on Public Companies. (Journal of Laws 2005, No. 184, pos. 1539, as amended).
} 
The minimum initial capital required for a joint-stock company is $100,000 \mathrm{zl}$, which is divided into shares. A share may not be worth less than 1 grosz.

Choosing a capital company as the organizational form of an enterprise is justified if its activity is to be conducted on a large scale. The establishment of such a company entails certain expenditures, primarily in the form of the initial capital, which must meet the minimum requirements. It's also necessary to incur the costs of maintaining the governing bodies of these companies. An advantage of choosing a capital company as the form of doing business is the significant limitation on liability it affords. It's only the company itself that is liable to creditors. Shareholders are not liable for the debts of the company, at least in a legal sense.

If the SYNAT platform operator were organized in the form of a joint-stock company, it would be important to note the position taken by the Supreme Court - Civil Chamber, stated in its Resolution of 13 January 2006 (III CZP 122/2005 (OSNC 2006/12 poz. 200)), where it ruled that a "joint-stock company conducting socially useful activity in the sphere of public tasks specified in the Public Benefit and Volunteer Work Act of 24 April $2003^{11}$ and not operating for the purpose of making a profit may acquire the status of a public benefit organization".

It should be noted, however, that non-government organizations and other entities may acquire the status of public benefit organization provided that they have conducted socially useful activity in the sphere of public tasks continuously for at least 2 years. Moreover, non-government organizations and other entities subject to entry in the National Court Register acquire the status of public benefit organization the moment information is added to the Register stating they have met these requirements on the terms and in the manner prescribed in the National Court Register Act of August $20,1997^{12}$.

Pursuant to art. 24 of the Public Benefit and Volunteer Work Act of 24 April 2003, public benefit organizations are exempt from:

- corporate income tax,

- property tax,

- taxes on civil law transactions,

- stamp duty (treasury fees),

- court fees

\footnotetext{
${ }^{11}$ Journal of Laws 2003, No. 96, pos. 873.

12 Journal of Laws 1997, No. 121, pos. 769.
}

in relation to the public benefit activities they conduct.

Public benefit organizations may be charged with the performance of public tasks in two forms: 1) being entrusted with performing public tasks, and being provided grants to finance their realization; 2) supporting the performance of public tasks, and being provided grants to co-finance their realization.

Public benefit activity is not business activity, though it may be conducted either free of charge or for a charge. Public benefit activity conducted for a charge is: 1) activity conducted in the sphere of public tasks for which remuneration is collected;2) the sale of goods or services produced or rendered by persons directly benefitting from public benefit activity.

Revenue from public benefit activity conducted for a charge is devoted solely to conducting the public benefit activity ${ }^{13}$.

Public administration bodies support the realization of public tasks by public benefit organizations and entrust the performance of public tasks to them. This takes place after conducting an open tender, unless separate regulations provide for a different mode of commissioning. Supporting and entrusting these tasks may take place on the terms and under the provisions of Public-Private Partnership.

A prototype for another organizational-legal form that the SYNAT platform operator could adopt is the National Depository for Securities (KDPW).

In Poland, KDPW is the central institution responsible for the management and supervision of the depositorysettlement system in relation to trading in financial instruments in Poland. Essentially, it's an electronic platform on which financial instruments are registered (depository) and transactions in securities trading are settled; it also realizes the obligations of issuers to investors ${ }^{14}$.

KDPW functions as a self-supporting, independent joint-stock company. A third of its shares belong to the State Treasury, represented by the Minister of the Treasury; a third, to the Warsaw Stock Exchange; and a third to the National Bank of Poland (NBP). Shares in the Company may be acquired only by operators of financial instrument trading platforms, investment firms, banks, the State Treasury, NBP and legal

\footnotetext{
${ }^{13}$ Art. 6-8 Public Benefit and Volunteer Work Act of 24 April 2003 (Journal of Laws 2010, No. 234, pos. 1536).

${ }^{14}$ This list, of course, does not exhaust all the tasks performed by KDPW.
} 
Table 2. Comparison of funding prospects for the SYNAT platform operator according to organizational-legal form (source: the author of this report)

\begin{tabular}{|c|c|c|}
\hline organizational form & strengths & weaknesses \\
\hline executive agency & $\begin{array}{l}\text { - } \text { certainty of funding } \\
\text { - ease of obtaining funding from the national } \\
\text { budget } \\
\text { - possibility of obtaining funding from defined } \\
\text { sources of revenue earned from activities }\end{array}$ & $\begin{array}{l}\text { lack of incentives to maximize } \\
\text { revenue } \\
\text { no way to obtain private funding } \\
\text { (sponsoring) }\end{array}$ \\
\hline state legal person & $\begin{array}{l}\text { - ease of obtaining funding from the national } \\
\text { budget } \\
\text { - greater possibility of obtaining funding from } \\
\text { defined sources of revenue earned from activities }\end{array}$ & $\begin{array}{l}\text { - lack of incentives to maximize } \\
\text { revenue } \\
\text { - no way to obtain private funding } \\
\text { (sponsoring) }\end{array}$ \\
\hline foundation & $\begin{array}{l}\text { possibility of obtaining funding from revenue } \\
\text { generated by activities } \\
\text { - funding can be obtained from donations } \\
\text { and bequests } \\
\text { - tax breaks for foundations with the status } \\
\text { of public benefit organization }\end{array}$ & $\begin{array}{l}\text { - no way to obtain funding } \\
\text { from the national budget } \\
\text { - public funding can be obtained } \\
\text { only on a competitive basis }\end{array}$ \\
\hline $\begin{array}{l}\text { company } \\
\text { with status } \\
\text { of a public benefit } \\
\text { organization }\end{array}$ & $\begin{array}{l}\text { - possibility of obtaining funding from various } \\
\text { revenue-generating activities } \\
\text { - the greatest prospects for obtaining } \\
\text { funding from financial markets } \\
\text { - tax breaks for foundations with the status } \\
\text { of public benefit organization }\end{array}$ & $\begin{array}{l}\text { - high founding and administration } \\
\text { costs } \\
\text { - no certainty of obtaining public } \\
\text { funding } \\
\text { - } \text { public funding can be obtained } \\
\text { only on a competitive basis }\end{array}$ \\
\hline $\begin{array}{l}\text { non-profit } \\
\text { company }\end{array}$ & $\begin{array}{l}\text { - full autonomy in shaping sources of revenue } \\
\text { - the greatest prospects for obtaining } \\
\text { funding from financial markets } \\
\text { - possibility of reducing the government's stake in } \\
\text { the company }\end{array}$ & $\begin{array}{l}\text { - high founding and administration } \\
\text { costs } \\
\text { - public funding can be obtained } \\
\text { only on a competitive basis }\end{array}$ \\
\hline
\end{tabular}

persons or other organizational entities that conduct activity in the field of registering financial instruments as well as clearing or settlement of transactions in securities trading or the organizing of a regulated market and are based in a country that belongs to the EU, EEA or OECD, provided they are subject to supervision by the appropriate supervisory body of this country. The company's shares are exclusively ordinary and registered. The company is non-profit [20].

Securities depository participants may be investment firms, state institutions such as the Central Bank or State Treasury, issuers of securities, banks, insurance companies, pension funds and investment funds, provided they invest funds on their own account in the securities market, entities authorized to clear or settle transactions in financial instruments trading and foreign depositories of financial instruments.

KDPW's source of revenue are fees collected from participants for managing the depository, such as the fee for opening a formal account, fee for the management of an entity account, fees for safekeeping cash market instruments, shares, treasury bills and other securities (collected on a monthly basis, calculated according to the market value of the securities held on participants' registration accounts), settlement fees (collected on a monthly basis from participants who are settlement counterparties) and fees for additional services. Fees are also collected from issuers as participants in KDPW [15].

If the SYNAT platform operator assumed the form of a joint-stock company modelled after KDPW S.A. it should be established by the State Treasury (represented by representatives of Ministry of Science and Education, Ministry of Education, Ministry of Culture and National Heritage, Ministry of Administration and Digitization). It would be advisable to allow shares to be acquired by other entities that support science, culture and education - e.g. the National Centre for Research and Development, National Science Centre, Foundation for Polish Science and companies in which the State Treasury holds a stake, which would 
allow the government to gradually withdraw from the company in future ${ }^{15}$.

A summary of the strengths and weaknesses in respect to funding continuity of the possible organizationallegal forms for the SYNAT platform operator is presented in Table 2.

The platform's business partners should be: public and private institutions of higher learning, Polish Academy of Sciences, scientific and research institutes, Foundation for Polish Science, libraries, publishing houses and other entities that support science, culture and education. Institutions that keep repositories of the results of publicly funded research should be required to participate in the SYNAT platform. Participation by other repositories should be optional.

Revenue sources for the platform's operator would include server hosting fees, income from the sale of added services, proceeds from advertising etc. The basis for estimating the amount of these fees needs to be determined - what should the platform's operating expenses be referred to: the magnitude of a participant's resources, the quality of resources as measured by bibliometric points, average time lag from the moment an article is published to the moment it's archived, or some other metric? If the institution managing the SYNAT platform maintains its own repository, fees for depositing content in it would be paid by the content providers.

It should be noted that the form of joint-stock company modelled after the National Depository for Securities S.A. would pose an obstacle to using public funds to buy national licences for scientific data bases - this could be treated as public assistance for business entities, which in principle is prohibited in EU member states.

Subsidizing enterprises requires the permission of the European Commission. An alternative could be special grants awarded to platform participants; the total amount of the grants would cover the costs of buying such licences by a consortium coordinated by the platform. There would be no such problem in the case of a joint-stock company with the status of a public benefit organization.

\footnotetext{
${ }^{15}$ Interest in the education and science sector is beginning to be shown, for instance, by investment funds - Kopernik FIZAN, set up by TFI Copernicus, intends to invest in non-public institutions of higher learning, science centers and research institutions [17].
}

\section{$8 \quad$ Summary and conclusions}

The costs of obtaining content from foreign sources and digitization of domestic resources are the main expenses that will be incurred by the SYNAT platform, and are difficult to estimate precisely. The operating expenses of the institution administering the platform, according to conservative initial calculations, should not exceed 3 million $\mathrm{zl}$ a year (at current prices), and capital outlays should amount to about 1 million zł. More precise cost projections will require specification of technical assumptions.

Public funds should be used to buy licences granting access to the data bases of renowned publishers of scientific periodicals and to pay for the digitization of Polish knowledge and national heritage resources.

Publications that result from publicly funded research should be subject to mandatory archiving in Open Access repositories. Open mandates should be adopted by the institutions funding science in Poland: NCBiR, $\mathrm{NCN}$, institutions of higher learning, PAN, scientific institutes whose employees conduct publicly funded research within the scope of these institutes' statutory activity, and other institutions that distribute public funds for scientific grants. Other research sponsors could be encouraged to adopt Open Access mandates by means of tax preferences, for example.

The SYNAT venture will not generate sufficient revenue from its activities to cover the platform's operating expenses in the near future or in the long term. Thus, public funds must constitute its main source of revenue; private funding will only play a supplementary role.

There are three possible variants ensuring the SYNAT platform steady funding: a long-term programme established by the Government, a surcharge on Corporate Income Tax, or the payment of fees by authors or the institutions with which they are affiliated for depositing the results of publicly funded research in repositories.

Continuity of funding for a universal, open, repository hosting and communication platform for web-based knowledge resources for science, education and an open knowledge society based on the executive agency model will depend on the condition of the national budget.

The long-lasting and stable functioning of the SYNAT platform under the legal status of a state legal person, public foundation or state institution in the form of a joint-stock company would require that this institu- 
tion, and the other institutions linked to its network, be assured of steady (independent of short-term political pressures) sources of revenue constituting an alternative to uncertain direct funding from the national budget.

Calculation of fees for auto-archiving/ the CIT surcharge/ the amount of funding in a long-term programme should be based on the operating expenses of the repository network and the SYNAT platform operator.

An alternative to charging authors or their institutions for the costs of Open Access publication could be special public-private or private funds, the creation of which could be encouraged by tax preferences.

\section{$9 \quad$ References}

[1] Foundation - Centre for Public Opinion Research Act of 20 February 1997. Journal of Laws 1997, No. 30, pos. 163.

[2] Council of Ministers (i.e. the Government) resolution No. 176/2010 of 12 October 2010 on establishment of the KULTURA+ long-term programme.

[3] Government draft Budget Act 2012; parliamentary paper No. 44.

[4] Guide to Open Learning, ICM UW, 2009, p. 35.

[5] http://www.guardian.co.uk/science/2011/dec/08/publi cly-funded-research-open-access

[6] Implementation and Promotion of Open Access to Scientific and Educational Content. World Practices and Specific Polish Conditions. Projected Costs, Tools, Strengths and Weaknesses. ICM UW under the direction of Niezgódka M.

http://koed.org.pl/2012/01/ekspertyza-na-tematotwartego-dostepu-do-nauki-i-edukacji/

[7] Kisielnicki J. - On a Scientific and Technical Information System and Its Functioning in the Transformation Process [in] TRANSFORMACJE, No. 1-2, 2011, pp. 286-328.

[8] Kisielnicki J., Hajkiewicz-Górecka M., Rak J., Rak A., Mbewe R. - Proposed Business Model for the Institution Operating the Platform. Unpublished report. Stage B8, Łazarski University: Long-term funding model ensuring continuity of the scientific and technical information system. Phase 3: Report on the target business model for the institution operating the platform.

[9] Księżopolska I. - Electronic Resources as the Main Component of the World Scientific Information System. Manuscript.

[10] Kuchma I., Nikisch J.A. - Open Access Policy in Europe and the United States [at] II International Open Access Conference in Poland, Toruń, 14-15
January 2010, http://www.ebib.info/publications (lecture: 20.01.2012.).

[11] Open Digital Resources, http://mac.gov.pl/projekty/ (lecture: 20.01.2012).

[12] Owsiak S. - Public Finance. Theory and Practice. PWN Science Publishing House, Warsaw 2006.

[13] Proposed Models for Maintaining and Developing Scientific and Technical Information (Business Models). Report on realization of the milestone "Marketing strategy proposals" - rapport for the second half of 2011, Stage B6, Institute of Economics and Management, Faculty of Management and Social Communication, Jagiellonion University, Kraków-Warsaw 2011.

[14] Public Finance Act of 27 August 2009. Journal of Laws, 2009, No. 157, pos. 1240.

[15] Regulations of the National Depository for Securities, www.kdpw.pl (accessed on 20.01.2012).

[16] Rychlik M., Karwasińska E. - Hunting for Resources - a Strategy for Procuring Documents for the A. Mickiewicz University Repository,

https://repository.amu.edu.pl (lecture: 20.01.2012)

[17] Samcik M. - Investment Fund Will Help Invest in Private Institutions of Higher Education! wyborcza.biz., 23.01.2012.

[18] Announcement No. 18 of the Minister of Science and Higher Education (MNiSW) of 9 Sept. 2010 on Grants Awarded for Science. Official Journal of MNiSW, 2012, No. 4, pos. 81; Announcement of the Minister of Science and Higher Education of 19 January 2012 on Grants Awarded for Science for Expanding the IT Infrastructure of Science. Official Journal of MNiSW of 5 March 2012, pos. 8); Announcement of the Minister of Science and Higher Education of 28 August 2012 on Grants Awarded for Science for Expanding the IT Infrastructure of Science. Official Journal of MNiSW of 31 August 2012, pos. 59.

[19] Announcement No. 18 of the Minister of Science and Higher Education of 29 December 2010 on the Establishment of the Programme to Support Research Infrastructure Under the Fund for Polish Science and Technology. Official Gazette of the Government of the Republic of Poland No. 101, pos. 1185.

[20] The Statute of the National Depository for Securities, a Joint Stock Company (KDPW S.A.),

[21] http://www.kdpw.pl/en/rules/Documents/statut_e.pdf (accessed on 20.01.2012).

[22] Trzaskowski R. - Statutory Activity and Business Activity of Foundations - the Law and Practice. Oficyna Naukowa, Warsaw 2003.

[23] Zołoteńki P. - Information on Government Agencies. Office of Research, Chancellery of Parliament, Informacja No. 833, 2011. 